\title{
The Effect of Compensation and Work Environment on Non-Asn Employee Performance at Jember Government: The Path Role of Job Satisfaction
}

\author{
${ }^{1}$ Ervan Setiawan ${ }^{*},{ }^{2}$ Sri Wahyu Lely Hana, ${ }^{3}$ Arnis Budi Susanto \\ ${ }^{1,2,3}$ Economic and Business Faculty, Universitas Jember, Jalan Kalimantan 37, Jember 68132, Indonesia
}

\begin{abstract}
This study aims to determine the effect of compensation and work environment on performance through job satisfaction of non ASN employees of the Jember Regency Government. The population in this study was all non ASN employees of Jember Regency Government working period 2020. The sampling technique used was nonprobability sampling with a purposive sampling method that is the technique of determining the sample with certain considerations. The number of samples in this assessment was 52 respondents from the Regional Secretariat and all Agencies in the Jember Regency Government. This research uses primary data in the form of questionnaire. Data analysis method used in this study is the path analysis method. Based on the results of research and discussion shows that compensation has an effect on job satisfaction, work environment has an effect on job satisfaction, compensation has an effect on performance, the work environment has an effect on performance, and the work environment has an effect on Job Satisfaction
\end{abstract}

Keywords: Compensation, Work Environment, Job Satisfaction, Performance.

\section{Introduction}

The government has various work units consisting of the composition of the State Civil Apparatus (ASN) which supports the implementation of government. Each of these work units has the main task of each function which is useful for realizing the vision and mission of the government. The mechanism of the Regional Government in determining ASN needs both in quality and quantity is through existing regulatory procedures. These needs are manifested in the formation of the ASN formation, which is used to determine what position formation needed in the recruitment of prospective ASN candidates. In carrying out the government needed human resources with the right quantity for the implementation of an ideal performance. But in reality there is a limit to the amount of human resources that can be allocated to the Jember Regency Government. The Central Government provides limits by giving approval to the allocation of the number of employees needed by the Jember Regency for each year. As a result, many workers choose to become honorary or volunteer (sukwan) / Non ASN.

Jember Regency has a strategic position and role as one of the Regional Activity Centers (PKW) in the former Besuki Residency. To support maximum government administration activities, the Jember Regency Government has employees consisting of ASN and Non ASN, based on the Regulation of the Minister of Home Affairs of the Republic of Indonesia Number 33 of 2017 concerning General Guidelines for 2018 APBD Adjustments. The provision of honoraria for non-ASN employees is limited and only based on the consideration that the existence of non-ASN employees really has a role and a real contribution to the effectiveness of the implementation of activities. Seeing the importance of compensation and job satisfaction issues for non-ASN employees in the Jember Regency, the researchers determined the object of research in the Jember Regency Government, because human resources with the right quality and quantity are expected to produce good performance. An evaluation of the performance status of regional government operations conducted by the Ministry of Home Affairs has placed Jember at 143 national ranks. Public and Government Policy Observer who is also a Lecturer at the Faculty of Social and Political Sciences Unej Rahmad Hidayat 
said, there is still a lot of performance in the Jember Regency which is less than optimal, especially at the level of basic services, such as education, health and population administration services.

Based on LAKIP (Government Agencies Performance Accountability Report), Jember Regency in 2018 that some service performance points to the public received a category of underachievement, namely in improving infrastructure quality by $53.8 \%$, increasing connectivity between regions by $50 \%$ and $40.48 \%$. It can be seen from the data that there needs to be an improvement in the performance of government in Jember Regency.

\section{Literature Review}

\subsection{The Effect of Compensation on Job Satisfaction}

According to Handoko (2008) factors that influence job satisfaction include compensation because compensation can influence employee behavior to work more enthusiastically. Compensation is one of the potential tools for creating job satisfaction. Hasibuan (2005: 118) compensation is all income in the form of money, direct or indirect goods received by employees in return for services provided to the company. The results of research conducted by Nurcahyani and Adnyani (2016) show the effect of compensation on job satisfaction. The main priorities that need to be improved are the remuneration of basic daily needs, the structure of wage work, and the cleanliness of the workplace. Setiawati (2019) revealed that job satisfaction is an effort of the company to create a sense of security and satisfaction in working towards realizing company goals. Therefore the hypothesis developed is:

H1: Compensation affects the job satisfaction of non-ASN employees of the Jember Regency Government.

\subsection{The Effect of Work Environment on Job Satisfaction}

The work environment has a significant contribution to employee job satisfaction (Holman, 2002), so the employee work environment has a strong effect on job satisfaction (Hurley et al., 2000). The work environment is a condition of everything that is around the workplace of an employee who is able to exert influence on him in carrying out his work (Nitisemito, 2006: 106). Satisfaction will be higher and intention to leave will be lower if the work environment complements the requirements of work creativity (Shalley et al., 2000). The results of research conducted by Setiawati (2019), and Yasa (2019) stated that compensation and work environment directly have a positive and significant effect on job satisfaction. Compensation, work environment and job satisfaction directly have a positive and significant effect on performance. Therefore the hypothesis developed is:

$\mathrm{H} 2$ : The work environment affects the job satisfaction of non ASN employees of the Jember Regency Government

\subsection{The Effect of Compensation on Performance}

Employee performance is very important for a company in order to realize company goals. Performance produced by employees is very important for a company in order to realize company goals. Employee performance can be influenced by several factors, one of which is compensation, if the employee receives compensation according to his needs it will be able to improve employee performance. Compensation is an important component in relations with employees. In accordance with the opinion of Umar (2007: 16), Sedarmayanti (2011: 239), Rivai (2004: 357), compensation is something that is received by employees as a substitute for the contribution of their services to the company. This means that the compensation given by the agency affects the performance results positively or negatively, depending on the situation and conditions faced by the person concerned. Research conducted by Noval (2016), Nurcahyani (2016), Raitatha and Komera (2016), Setiawati (2019), and Yasa (2019) stated that compensation has a strong influence on performance. This means that if the compensation given by the agency matches the contribution of non-ASN employees to the agency, the performance of non-ASN employees will increase. Based on this explanation, the researcher proposes the following hypothesis:

H3: Compensation affects the performance of non-ASN employees of the Jember Regency Government 


\subsection{The Effect of Work Environment on Performance}

Work environments that are both physical and non-physical are highly expected by employees to work optimally, and vice versa if the environment is bad, then employees will not have satisfaction at work (Anas, 2013). Therefore, the situation and situation around employees at work must be maintained as well as possible so that employees will feel comfortable at work. A work environment that includes harmonious working relationships, clear targets, a dynamic work climate and adequate work facilities can also affect employee job satisfaction (Mangkunegara dalam Dhermawan, 2012). Therefore the work environment has an influence on employee job satisfaction. Research conducted by Nurcahyani (2016), Raitatha and Komera (2016), Setiawati (2019), and Yasa (2019) stated that compensation has a strong influence on performance. This proves that the work environment is an important factor in increasing employee job satisfaction. Based on this explanation, the researcher proposes the following hypothesis:

H4: The work environment influences the performance of non ASN employees of the Jember Regency Government

\subsection{Effect of Job Satisfaction on Performance}

Job satisfaction can affect performance because job satisfaction plays an important role in the development of a company to improve employee efficiency and performance (Ahmed and Uddin, 2012). Job satisfaction is a positive or negative attitude from an employee's emotional view of his work whether indicated in a pleasant state or not (Handoko, 2001: 193). Employees who are able to use their skills and knowledge on the job will be very satisfied with the job (Berg, 1999). Employees tend to improve their performance both in terms of quantity and quantity if employee satisfaction is met (Pramitha et al., 2012). This is in accordance with research by Nurcahyani (2018), Setiyadi (2016), and Pratiwi (2017), and Freziamella (2014) which shows a positive influence between job satisfaction and performance, so from the description the proposed hypothesis is:

H5: Job satisfaction affects the performance of non-ASN employees of Jember Regency Government

\section{Methodology}

This research uses Explanatory Research, which is the type of research that aims to analyze the relationship or influence between variables through hypothesis testing. The population in this study was all non ASN employees of Jember Regency Government working period 2020. The sampling technique used was nonprobability sampling with a purposive sampling method that is the technique of determining the sample with certain considerations. The number of samples in this assessment amounted to 52 respondents from the Regional Secretariat and all Agencies in the Jember Regency Government. This study uses primary data in the form of a questionnaire. The data analysis method used in this study is the path analysis method.

\section{Results and Discussion}

\subsection{Result}

\section{a. Characteristics of Respondents}

The following are descriptive statistics for each of the variables used in this study and data on respondent characteristics. The following are descriptive statistics for each of the variables used in this study and data on respondent characteristics. The data used in this study include the following data: Gender, Age, Education, and Length of Work. Descriptive data of respondents as follows:

\section{Table 1: Characteristics of Respondents}

\begin{tabular}{|l|l|l|}
\hline Gender & Qty & $(\boldsymbol{\%})$ \\
\hline Male & 21 & 40,4 \\
\hline Female & 31 & 59,6 \\
\hline Age & Qty & $(\boldsymbol{\%})$ \\
\hline $21-30$ yo & 24 & 46,1 \\
\hline $31-40$ yo & 18 & 34,6 \\
\hline
\end{tabular}




\begin{tabular}{|l|l|l|}
\hline $41-50 y o$ & 10 & 19,3 \\
\hline Education & Qty & $(\%)$ \\
\hline Senior High School & 8 & 15,3 \\
\hline Diploma & 17 & 32,8 \\
\hline Bachelor & 26 & 50 \\
\hline Master & 1 & 1,9 \\
\hline Length of work & Qty & $\mathbf{( \% )}$ \\
\hline $5-10$ yrs & 28 & 53,9 \\
\hline $5-15$ yrs & 22 & 42,3 \\
\hline$>15$ yrs & 2 & 3,8 \\
\hline
\end{tabular}

\section{Source: Primary data processed, 2020}

Table 1 shows that the majority of female respondents were 31 people (59.6\%) and the number of male respondents was $21(40.4 \%)$. The number of respondents aged 18-25 years as many as 14 people $(12.1 \%)$, aged 26-35 years as many as 31 people (26.9\%), aged 41-50 years, as many as 48 people (41.7\%) and aged> 46 years, as many as 22 people $(19.3 \%)$. The number of respondents based on high school education is 8 people (15.3\%), Diploma is 17 people $(32.8 \%)$, S1 is 26 people $(50 \%)$, and others are 10 people $(8.8 \%)$. The number of respondents based on working time of 5-10 years is as many as 28 people (53.9\%), 10-15 years as many as 22 people (42.3\%), and > 15 years as many as 2 people $(3.8 \%)$.

\section{b. Path Analysis}

Path analysis is part of the regression analysis used to analyze the relationship between variables, where the independent variables affect the dependent variable directly or indirectly through one or more intermediaries (Sarwono, 2006: 147). In contrast to the regression equation where the effect of the independent variable on the dependent variable is only in the form of a direct effect, in the linear structural equation the effect of the free variable on the dependent variable can be in the form of direct and indirect effects. The indirect effect of a free variable on a dependent variable is through another variable called an intervening variable or intermediary variable. The total effect of the independent variable on the dependent variable is the sum of the direct effects and all indirect effects. The results of the path analysis are presented in the figure as follows:

\section{Table 2: Path Analysis Variable}

\begin{tabular}{|c|c|c|c|c|}
\hline \multicolumn{2}{|l|}{ Standarized } & \multirow{2}{*}{ Sig } & \multirow{2}{*}{$\alpha$} & \multirow{2}{*}{ Expl } \\
\hline Path & Beta & & & \\
\hline $\mathrm{X} 1 \quad \vec{Z}$ & 0,310 & 0,000 & 0,05 & Significant \\
\hline $\mathrm{X} 2 \quad \overrightarrow{\mathrm{Z}}$ & 0,294 & 0,001 & 0,05 & Significant \\
\hline $\mathrm{X} 1 \quad \overrightarrow{\mathrm{Y}}$ & 0,186 & 0,011 & 0,05 & Significant \\
\hline$\vec{P}$ & 0,342 & 0,001 & 0,05 & Significant \\
\hline $\mathrm{Z} \quad \overrightarrow{\mathrm{Y}}$ & 0,417 & 0,005 & 0,05 & Significant \\
\hline
\end{tabular}

\section{Source: data processed}

Based on Table 2, to analyze the first path can be explained that between Compensation (X1) with Job Satisfaction $(Z)$ has a significant effect. This can be seen by the results of a significant value that is 0,000 less than $\alpha=0.05$. The second path between the Work Environment (X2) and Job Satisfaction (Z) has a significant effect that is equal to 0.001 smaller than $\alpha=0.05$. The third path between Compensation (X1) and Performance (Y) has a significant effect that is equal to 0.011 smaller than $\alpha=0.05$. The fourth path 
between the Work Environment (X2) with Performance (Y) has a significant effect of 0.001 which is smaller than $\alpha=0.05$. The fifth path between Job Satisfaction (Z) and Performance (Y) has a significant effect of 0.005 which is smaller than $\alpha=0.05$. The results of the path analysis can be seen in the following figure:

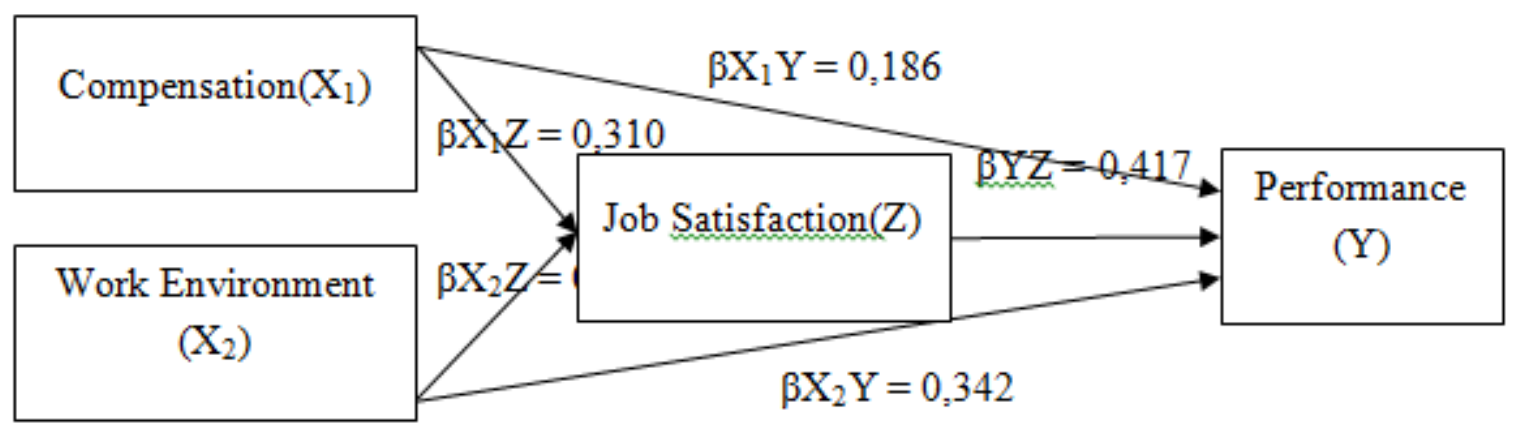

Figure 1; Path Analysist

The path coefficient is calculaed by making a structural equation that is a regression equation that shows the relationship. The path analysis model in the equation is as follows:

$$
\begin{aligned}
& \mathrm{Z}=0,310 \mathrm{X} 1 \mathrm{Z}+0,294 \mathrm{X} 2 \mathrm{Z}+e \ldots \ldots \ldots \ldots \ldots \ldots .(\text { Equation } 1) \\
& \mathrm{Y}=0,186 \mathrm{X} 1 \mathrm{Y}+0,342 \mathrm{X} 2 \mathrm{Y}+0,417 \mathrm{ZY}+e \ldots \ldots \ldots(\text { Equation } 2)
\end{aligned}
$$

\section{c. $T$ test}

T test is used to determine whether the independent variable $(\mathrm{X})$ is influenced by the dependent variable $(\mathrm{Y})$ (Sugiyono, 2002: 84). T test results are as follows:

\section{Table 3: T test}

\begin{tabular}{|lll|l|}
\hline \multicolumn{2}{|l|}{ Variable } & \\
\hline $\mathrm{X} 1 \mathrm{Z} \quad \longrightarrow$ & Sig \\
\hline $\mathrm{X} 2 \mathrm{Z} \quad \longrightarrow$ & & 0,000 \\
\hline $\mathrm{X} 1 \mathrm{Y}$ & $\longrightarrow$ & 0,001 \\
\hline $\mathrm{X} 2 \mathrm{Y}$ & $\longrightarrow$ & 0,011 \\
\hline & $\mathrm{Z} \longrightarrow \mathrm{Y}$ & 0,001 \\
\hline
\end{tabular}

\section{Source: data processed}

Based on table 3 it can be seen the magnitude of the effect of each independent variable on the dependent variable as follows:

\section{Compensation on Work Satisfaction}

Based on Table 3 it can be seen that the significance level $(\alpha)$ of the Compensation is $0,000<0.05$. This means that compensation has a significant effect on job satisfaction.

\section{Work Environment on Job Satisfaction}

Based on Table 3 it can be seen that the significance level $(\alpha)$ of the Work Environment is $0.001<0.05$. This means that the work environment has a significant effect on job satisfaction.

\section{Compensation on Performance}

Based on Table 3 it can be seen that the significance level $(\alpha)$ of the Compensation is $0.011<0.05$. This means that Compensation has a significant effect on performance.

\section{Work Environment on the Performance}

Based on Table 3 it can be seen that the significance level $(\alpha)$ of the Work Environment is $0.001<0.05$. This means that the work environment has a significant effect on performance. 


\section{Job Satisfaction on the Performance}

Based on Table 3 it can be seen that the significance level $(\alpha)$ of the Job Satisfaction is $0.005<0.05$. This means that job satisfaction has a significant effect on performance.

\subsubsection{Path}

Path calculation explains about Compensation (X1), Work Environment (X2) and Job Satisfaction (X3), both directly and indirectly on Performance (Y), through intervening variables namely Job Satisfaction (Z). When all paths are significant, direct and indirect effects or total effects are calculated. Based on the following table, the results of the path coefficient calculation test:

\section{a. Direct Effect}

1) The direct effect of the Compensation variable on Job Satisfaction is $31 \%$

2) The direct effect of the Work Environment variable on Job Satisfaction is $29.4 \%$

3) The direct effect of the Compensation variable on Performance is $18.6 \%$

4) The direct effect of the Work Environment variable on Performance is $34.2 \%$

5) The direct effect of the Job Satisfaction variable on Performance is $41.7 \%$

\section{b. Indirect Effect}

1) The indirect effect of the Compensation variable through Job Satisfaction on Performance $(0.310 \mathrm{x}$ $0.417)=0.091$ or $9.1 \%$

2) The indirect effect of the Work Environment variable through Job Satisfaction on Performance $(0.294 \times 0.417)=0.122$ or $12.2 \%$

\section{c. Total Effect}

1) Total effect: $Y \quad X 1 \rightarrow Z \rightarrow Y, 0,186+0,091=$ or 0,277 or $27,7 \%$

2) Total effect: $Y \quad X 2 \rightarrow Z \rightarrow Y, 0,342+0,122=$ or 0,464 or $46,4 \%$

\subsection{Discussion}

\section{Compensation affects Job Satisfaction}

The results of the path analysis on the t-test of the first hypothesis (H1) show that Compensation has an effect on the satisfaction of Kerjadengan seeing the significance level of 0,000. The relationship shown by the regression coefficient is positive, meaning that the better Compensation, the Job Satisfaction will increase (H1 accepted).

According to Handoko (2008) factors that influence job satisfaction include compensation because compensation can influence employee behavior to work more enthusiastically. Compensation is one of the potential tools for creating job satisfaction. Hasibuan (2005: 118) compensation is all income in the form of money, direct or indirect goods received by employees in return for services provided to the company.

The results of this study are in line with previous studies conducted by Nurcahyani and Adnyani (2016) showing the effect of compensation on job satisfaction. The main priorities that need to be improved are the remuneration of basic daily needs, the structure of wage work, and the cleanliness of the workplace. Setiawati (2019) revealed that job satisfaction is an effort of the company to create a sense of security and satisfaction in working towards realizing company goals.

\section{Work Environment affects Job Satisfaction}

The results of the path analysis on the $t$ test of the second hypothesis (H2) show that the Work Environment influences Job Satisfaction by looking at the significance level of 0.001 . The relationship shown by the regression coefficient is positive, meaning that the higher the Work Environment, the Job Satisfaction will increase (H2 is accepted). The work environment has a significant contribution to employee job satisfaction (Holman, 2002), so the employee work environment has a strong effect on job satisfaction (Hurley et al., 2000). The work environment is a condition of everything that is around the workplace of an employee who is able to exert influence on him in carrying out his work (Nitisemito, 2006: 106). Satisfaction will be higher and intention to leave will be lower if the work environment complements the requirements of work creativity (Shalley et al., 2000).

The results of this study are in line with previous studies conducted by Setiawati (2019), and Yasa (2019) states that compensation and work environment directly have a positive and significant effect on job 
satisfaction. Compensation, work environment and job satisfaction directly have a positive and significant effect on performance.

\section{Compensation affects Performance}

The results of the path analysis on the t test of the third hypothesis (H3) show that compensation affects the performance by looking at the significance level of 0.011 . The relationship shown by the regression coefficient is positive, meaning that the better the compensation, the performance will increase $(\mathrm{H} 3$ accepted).Employee performance is very important for a company in order to realize company goals. Performance produced by employees is very important for a company in order to realize company goals. Employee performance can be influenced by several factors, one of them is compensation. If the employee receives compensation according to his needs it will be able to improve employee performance. Compensation is an important component in relations with employees. In accordance with the opinion of Umar (2007: 16), Sedarmayanti (2011: 239), Rivai (2004: 357), compensation is something that is received by employees as a substitute for the contribution of their services to the company. This means that the compensation given by the agency affects the performance results positively or negatively, depending on the situation and conditions faced by the person concerned.

The results of this study are in line with previous studies conducted by Noval (2016), Nurcahyani (2016), Raitatha and Komera (2016), Setiawati (2019), and Yasa (2019) states that compensation has a strong influence on performance. This means that if the compensation given by the agency matches the contribution of non-ASN employees to the agency, the performance of non-ASN employees will increase.

\section{Work environment influences Performance}

The results of the path analysis on the $t$ test of the fourth hypothesis (H4) show that the Work Environment influences Performance by looking at the significance level of 0.001 . The relationship shown by the regression coefficient is positive, meaning that the higher the Work Environment, the performance will increase (H4 is accepted).Work environments that are both physical and non-physical are highly expected by employees to work optimally, and vice versa if the environment is bad, then employees will not have satisfaction at work (Anas, 2013). Therefore, the situation and situation around employees at work must be maintained as well as possible so that employees will feel comfortable at work. A work environment that includes harmonious working relationships, clear targets, a dynamic work climate, and adequate work facilities can also affect employee job satisfaction (Mangkunegara dalam Dhermawan, 2012). Therefore the work environment has an influence on employee job satisfaction.

The results of this study are in line with previous studies conducted by Nurcahyani (2016), Raitatha and Komera (2016), Setiawati (2019), and Yasa (2019) states that compensation has a strong influence on performance. This proves that the work environment is an important factor in increasing employee job satisfaction.

\section{Job Satisfaction affects Performance}

The results of the path analysis on the $t$ test of the fifth hypothesis (H5) show that Job Satisfaction influences Performance by looking at the significance level of 0.005 . The relationship shown by the regression coefficient is positive, meaning that the higher the Job Satisfaction, the performance will increase (H5 accepted).Job satisfaction can affect performance because job satisfaction plays an important role in the development of a company to improve employee efficiency and performance (Ahmed and Uddin, 2012). Job satisfaction is a positive or negative attitude from an employee's emotional view of his work whether indicated in a pleasant state or not (Handoko, 2001: 193). Employees who are able to use their skills and knowledge on the job will be very satisfied with the job (Berg, 1999). Employees tend to improve their performance both in terms of quantity and quantity if employee satisfaction is met (Pramitha et al., 2012).

The results of this study are in line with previous studies conducted by Nurcahyani (2018), Setiyadi (2016), and Pratiwi (2017), and Freziamella (2014) which showed a positive influence between job satisfaction and performance.

\section{Conclusion}

a. The test results show a significant difference. This proves that good compensation will increase job satisfaction. 
b. The results showed a significant difference. This proves that good compensation will increase job satisfaction.

c. The test results of the Composition to Performance comparison show a significant positive. This proves that good compensation will improve performance.

d. Test Results of Environmental Performance on Performance showed a significant positive. This proves that good compensation will improve performance.

e. Test Results on Job Satisfaction on Performance Shows a significant positive. This proves that Job Satisfaction will improve Performance Prove that Job Satisfaction will improve Performance.

\section{References}

[1.] Akdon, Riduwan. 2011. Rumus dan Data dalam Aplikasi Statistika. Bandung:Alfabeta.

[2.] Annisa Rizki Nugraheni. 2018. Pengaruh Kepuasan kerja Terhadap Kinerja Karyawan PT. Taspen Persero Malang.Jurnal Administrasi Bisnis (JAB) Vol. 58 No. 1

[3.] Arifin, Noor. 2012. Analisis Kualitas Kehidupan, Kinerja, dan Kepuasan Kerja pada CV. Duta Senenan Jepara. Jurnal Economia, Volume 8, Nomor 1.

[4.] Arristra, Honey Desy. 2016. Pengaruh Kompensasi, Beban kerja dan Kualitas Pelayanan terhadap Kinerja Karyawan Rawat Inap dan Rawat Jalan RSD dr. Soebandi Jember. Skripsi. Universitas Jember.

[5.] Basri, Rivai.2005.Performance Appraisal. Cetakan Pertama, PT.Raja Grafindo Persada, Jakarta.

[6.] Blanco, Gabriel Vidal. dkk. 2018. Kepuasan kerja and self-care in nursing staff with high emotional demand. Enfermería Clínica (English Edition), In press, corrected proof.

[7.] Cascio, Wayne F. 2003. Managing Human Resources. Colorado: Mc Graw-Hill

[8.] Cascio, W. F. 2006. Managing Human Resources: Productivity, Quality of Work-Life, profits.(2nd ed.). New York: McGraw-Hill

[9.] Chandranshu, S. 2012. Factors AffectingKepuasan kerja: Empirical Evidence From IndianOrganizations. Australian Journal of Businessand Management Research, Vol.1 No.11, 3140.

[10.] Dhermawan, A.A Ngurah Bagus. 2012. Pengaruh Motivasi, Lingkungan Kerja, Kompetensi dan Kompensasi Terhadap Kepuasan Kerja dan Kinerja Pegawai Di Ling. Kantor Dinas Pekerjaan Umum Prov. Bali. Jurnal Manajemen, Strategi Bisnis, dan Kewirausahaan Vol. 6, No.2

[11.] Dubrin, Adrew. 1994. Human Relation A Job OrientedApproach.Virginia:Reston Publishing Company,Inc.

[12.] Fauzi, Usman. 2014. Pengaruh Kompensasi Terhadap Kinerja Karyawan Pada PT. Trakindo Utama Samarinda. eJournal Ilmu Administrasi Bisnis. 2 (3) : 172 - 185

[13.] Firmandari, Nuraini. 2014. Pengaruh Kompensasi Terhadap Kinerja Karyawan Dengan Motivasi Kerja Sebagai Variabel Moderasi Studi Pada Bank Syariah Mandiri KC Yogyakarta. Jurnal Ekonomi dan Bisnis Islam Vol. IX, No. 1 hal 25-34

[14.] Flippo, E.B. (2005). Manajemen Personalia.Jilid 2.Edisi ke-6.Terjemahan. Jakarta: Erlangga.

[15.] Ghozali, Imam. 2002. Aplikasi Analisis Multivariat dengan Program SPSS.Semarang: Badan Penerbit Universitas Diponegoro.

[16.] Ghozali, Imam. 2007. Aplikasi AnalisisMultivariate Dengan Program SPSS,Universitas Diponogoro, Semarang.

[17.] Mangkunegara, A.A. Anwar Prabu. 2009. Manajemen Sumber Daya Manusia. Bandung: PT. Remaja Rosdakarya.

[18.] Marthadinata, Sari dan Sentot Eko Baskoro.2018.Pengaruh Kompensasi, Komunikasi dan Lingkungan Kerja terhadap Kepuasan kerja Guru di Yayasan Kristen Bethany cabang Depok.

[19.] Mathis,R.L. dan J.H. Jackson. 2002. Manajemen Sumber Daya Manusia. Jakarta: Salemba empat.

[20.] Nawawi, Hadari. 2008. Manajemen Sumber Daya Manusia. Cetakan Ketujuh. Yogyakarta : Gadjah Mada University Press

[21.] Narehan,Hassan. Maamor Hairunnisa, Razak A. Norfadzillah, Lapok Freziamella. 2014. The Effect of Kepuasan kerja (QWL) Programs on Quality of Life (QOL) among Employees at Multinational Companies in Malaysia. Procedia-Social and Behavioral Sciences. Volume 112, 7 February 2014, Pages 24-34. 
[22.] Nugraha, Noval K. 2016. Pengaruh Kompensasi Terhadap Kinerja Tenaga Kerja Honorer Di Instansi Badan Pengelola Keuangan Dan Aset Daerah Provinsi Sumatera Selatan.Skripsi. Universitas Palembang.

[23.] Nurcahyani, Ni Made dan I.G.A. Dewi Adnyani.2016.Pengaruh Kompensasi Dan Motivasi Terhadap Kinerja Karyawan Dengan Kepuasan Kerja Sebagai Variabel Intervening. E-Jurnal Manajemen Unud, Vol. 5, No.1, 500-532.

[24.] Potale, Rocky dan Yantje Uhing.2015.Pengaruh Kompensasi Dan Stres Kerja Terhadap Kepuasan Kerja Karyawan Pada PT. Bank Sulut Cabang Utama Manado. Jurnal EMBA.

[25.] Robbins, Stephen P. 2001. Perilaku Organisasi: Konsep, Kontroversi, Aplikasi, Jilid 1, Edisi 8,Prenhallindo, Jakarta.

[26.] Rochaety, Ety.2007.Metodologi Penelitian Bisnis dengan aplikasi SPSS. Jakarta: Mitra Wacana Media.

[27.] Samsudin, Sadili. 2006. Manajemen Sumber Daya Manusia. Bandung: CV. PustakaSetia.

[28.] Sarwono.2006. Metode Penelitian Kuantitatif dan Kualitatif.Yogyakarta :Graha Ilmu

[29.] Sedarmayanti. 2011.Manajemen Sumber Daya Manusia, Reformasi Birokrasi danManajemen Pegawai Negeri Sipil (cetakan kelima). Bandung: PT. RefikaAditamaSugiyono. 2004.Metode Penelitian Bisnis. Bandung: Alfabeta.

[30.] Sugiyono. 2013. Metode PenelitianPendidikanPendekatan Kuantitatif, Kualitatif, dan R\&D. Bandung: Alfabeta.

[31.] Suprapto, Tommy.Pengantar Teori dan Manajemen Komunikasi.Cet. 8. 2009. Yogyakarta: MedPress.

[32.] Umar, Husein. 2007. Riset Sumber Daya Manusia, Gramedia Pustaka Utama, Jakarta.

[33.] Wang. 2018. Does CEO compensation reflect managerial ability or managerial power? Evidence from the compensation of powerful CEO's.Journal of Corporate Finance. 